\title{
ANALISIS SISTEM INFORMASI AKUNTANSI ZAKAT, INFAK, SEDEKAH (ZIS) PADA BAZ DI JAWA TIMUR
}

\author{
Ahmad Hasan Bashori \\ Mahasiswa Alumni FEBI UIN SA Surabaya | bashori.hasan@ gmail.com
}

\begin{abstract}
Abstrak:Penelitian ini membahas tentang Sistem Infomasi Akuntansi Zakat, Infak, Sedekah (ZIS) pada BAZ di Jawa Timur. Penelitian ini ditulis untuk mengetahui pelaksanaan sistem informasi akuntansi pada BAZ di Jawa Timur dan membahas tentang kesesuaian laporan keuangan BAZ di Jawa Timur dengan PSAK No. 109. Penelitian ini merupakan hasil penelitian lapangan (fieldresearch) dengan menggunakan metode pengumpulan data melalui wawancara, observasi, dan dokumentasi. Hasil penelitian menunjukkan penerapan sistem informasi akuntansi oleh BAZ di Jawa Timur masih belum efektif dan efisien karena masih menggunakan sistem manual begitu juga tidak digunakannya program yang diberikan oleh BAZN AS pusat yang dapat membantu kinerja BAZ di Jawa Timur, serta sistem akuntansi yang diterapkanoleh BAZ di Jawa Timur masih belum menggunakan PSAK N 0. 109. Pada sistem prosedur pembuatan laporan keuangan, hanya menggunakan laporan arus kas saja dan masih belum mengacu pada PSAK 109. Adanya praktik yang kurang sehat dalam melaksanakan tugas dan fungsi yakni tidak adanya nomor urut formulir bukti penerimaan dana sehingga menimbulkan potensi manipulasi. Selain itu, pengendalian internal BAZ di Jawa Timur belum maksimal karena tidak ada pengawasan khusus yang dilakukan oleh pengurus BAZ di Jaw a Timur kepada pelaksana harian.
\end{abstract}




\section{Pendahuluan}

BAZ di Jawa Timur sebagai pengelola zakat infak, dan sedekah mempunyai tugas melaksanakan pengumpulan, pendistribusian, dan pendayagunaan ZIS sesuai dengan ketentuan agama, dan tugas lain yang berkaitan dengan pengelolaan ZIS sesuai dengan perundang-undangan yang berlaku.

Untuk mempertanggungjawabkan tugasnya maka BAZ di Jawa Timur perlu meningkatkan pengelolaan sistem informasinya. Apalagi yang menyangkut tentang sistem informasi akuntansi lembaga itu sendiri.

Di masa sekarang ini, apalagi pada masa yang akan datang, tugas-tugas atau pekerjaan manusia dalam organisasi banyak yang telah dapat digantikan oleh komputer termasuk dalam bidang akuntansi. ${ }^{1}$

Sistem informasi merupakan suatu cara dalam menyelesaikan masalah sedemikian rupa sehingga menghasilkan suatu hasil atau laporan yang berupa sesuatu yang bisa diterima, dan dimanfaatkan oleh pihakpihak yang berkepentingan. ${ }^{2}$

Informasi juga diperlukan untuk mendukung pengambilan keputusan yang tidak rutin pada semua tingkat dari suatu organisasi. Suatu sistem informasi juga diperlukan untuk aktivitas perencanaan, dan pengendalian. ${ }^{3}$

Melalui Sistem Informasi Akuntansi (SIA) yang baik akan menghasilkan informasi yang bermanfaat bagi pemakai laporan keuangan. Dengan menggunakan sistem informasi akuntansi ZIS, lembaga

${ }^{1}$ TataSutabri,SistemInformasiAkuntansi,(Yogyakarta:AndiO ffset,2004),1

${ }^{2} \mathrm{M}$.Faisal,SistemInformasiM anajemenJaringan,(Yogyakarta:U IN M alang Press,2008)

${ }^{3}$ D asarathaV.Rama, danFrederickL.Jones,SistemInfo rmasiAkuntansi,(Jakarta:Salemba Empat,2008),8

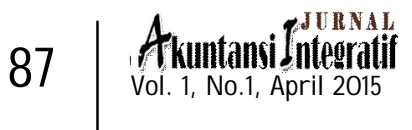


pengelola zakat dapat mencatat, dan melaporkan arus zakat dengan baik.

Namun demikian setelah peneliti mengamati dalam kurun waktu beberapa minggu di tempat penelititan, ditemukan beberapa permasalahan. Peneliti menemukan suatu hal yang mengejutkan, bahwa penomoran formulir bukti penerimaan, dana ZIS masih ditulis secara manual bahkan ada BAZ yang tidak menggunakan penomoran dalam pencatatan penerimaan, dana ZIS. Peneliti membuktikannya sendiri dengan menggunakan sumber terpercaya bahwa penerimaan, dana ZIS yang peneliti berikan tidak ditulis penomorannya. Secara administrasi menurut pendapat peneliti hal tersebut merupakan kesalahan dasar yang seharusnya tidak terjadi. Karena efek kesalahan tersebut dapat menimbulkan permasalah serius seperti halnya potensi manipulasi, juga dapat menimbulkan presepsi negatif oleh masyarakat tentang profesionalitas BAZ di Jawa Timur.

Selanjutnya, peneliti juga menemukan proses manajemen data yang kurang efektif, dan efisien pada BAZ di Jawa Timur. Yakni proses pencatatan dalam setiap transaksi mayoritas masih menggunakan sistem manual bahkan program aplikasi yang sudah diberikan oleh Badan Amil Zakat Nasional (BAZNAS) pusat tidak digunakan. Menurut peneliti hal tersebut sangat merugikan dari segi keefektifan proses manajemen BAZ di Jawa Timur. Akibatnya dalam hal proses pengelolaan dana ZIS menjadi kurang efektif, dan efisien.

Kemudian yang terakhiradalah sistem akuntansi yang ada pada BAZ di Jawa Timur yang meliputi BAZ Kota Mojokerto, BAZ Gresik, BAZ Sidoarjo, dan BAZ Jatim masih belum menerapkan PSAK (Pernyataan Standar 
Akuntansi Keuangan) No.109 secara menyeluruh dibuktikan dengan penyajian laporan keuangan yang mengandalkan laporan arus kas saja. Sehingga menimbulkan presepsi peneliti bahwa BAZ di Jawa Timur belum menggunakan PSAK No.109 secara keseluruhan. Begitu juga laporan keuangan BAZ di Jawa Timur yang sebatas diperiksa auditor internal yang dilakukan oleh pengurus BAZ itu sendiri. Menurut peneliti seharusnya demi menjalankan amanah, dan membangun kepercayaan masyarakat, laporan keuangan BAZ di Jawa Timur sebaiknya di audit oleh auditor independen. Adanya permasalahan yang ada pada BAZ di Jawa Timur yang telah peneliti jelaskan di atas, maka perlu adanya pengelelolaan sistem informasi akuntansi yang baik tanpa meninggalkan pedoman PSAK No. 109 sehingga menghasilkan sistem informasi akuntansi yang efektif, dan efisien. Pada akhirnya hal tersebut dapat mempermudah siapa saja untuk mendapatkan informasi yang jelas sehingga menambah kepercayaan dari masyarakat juga membangun profesionalitas BAZ di Jawa Timur.

Meskipun penilaian secara penerimaan ZIS pada BAZ di Jawa Timur tebilang besar, dan potensial. Berdasarkan Laporan Tahunan BAZ kota Mojokerto pada akhir tahun 2012 telah diketahui, bahwa penerimaan ZIS telah mengalami kenaikan sebesar $26 \%$ dari tahun sebelumnya. ${ }^{4}$ BAZ Jawa Timur mengumpulkan, dana ZIS perbulan dengan rata-rata Rp 200juta samapai Rp 300 juta. ${ }^{5}$ BAZ Sidoarjo mengumpulkan, dana ZIS perbulan dengan rata-rata $\mathrm{Rp} 100$ juta. ${ }^{6}$ Sedangkan penerimaan,

${ }^{4}$ Ibid.,10.

${ }^{5}$ AbdulKholik, W awancara,Surabaya,18D esember2013

${ }^{6}$ Abd.Hakim,W awancara,Sidoarjo, 23D esember2013

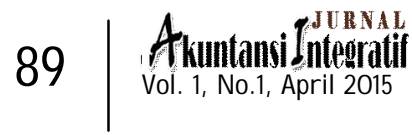


dana ZIS BAZ Gresik mencapai lebih dari Rp 100 juta pada bulan November tahun $2013 .^{7}$

Pertumbuhan positif, dan besarnya dana ZIS yang diterima tersebut tentunya menumbuhkan kebutuhan masyarakat terhadap akuntabilitas laporan ZIS yang dibuat. Berdasarkan tingkat kebutuhan informasi laporan zakat untuk publik sangat besar dirasakan oleh masyarakat karena untuk meningkatkan kepercayaan sekaligus tuntutan profesionalitas suatu lembaga, perluadanya penerapan sistem informasi akuntansi yang baik sebagai lembaga pengelola zakat.

Dengan demikian, peneliti tertarik untuk meneliti sistem informasi akuntansi ZIS yang adapada BAZ di Jawa Timur sehingga dapat memberikan solusi bagaimana sistem informasi akuntansi ZIS yang dapat dikelola dengan benar sehingga berjalan lebih efektif, dan efisien.

\section{TinjauanPustaka}

\section{A. Siste Informai Akuntansi}

Sistem Informasi Akuntansi (SIA) itu adalah suatu subsistem dari SIM yang menyediakan informasi akuntansi dan keuangan, juga informasi lain yang diperoleh rutin atas transaksi akuntansi. ${ }^{8}$

SIA adalah sebuah sistem yang mengumpulkan, mencatat, menyimpan, dan memproses data sehingga menghasilkan infromasi yang berguna dalam membuat keputusan. SIA bisa berupa kertas dana lattulis (manual) maupun terkomputerisasi penuh (serba otomatis) atau kondisi diantara

\footnotetext{
${ }^{7}$ BadanAmilZakatPemerintahanKabupatenG resik,LaporanKeuanganBulanN ovember 2013 ${ }^{8}$ DasarathaV. Ramadan FrederickL. Jones, SistemInformasiAkuntansi,(Jakarta: SalembaEmpat,2008),6.
} 
keduanya (gabungan manualdankomputerisasi). Teknologi hanyalah alat untuk menyusun, memelihara, ataupun menyempurnakan sistem. ${ }^{9}$

Proses bisnis (business procces) adalah urutan aktivitas yang dilaksanakan oleh suatu bisnis untuk memperoleh, menghasilkan, serta menjual barang dan jasa. Para akuntan dan yang lain memiliki kepentingan dalam pemodelan proses bisnis. Beberapa model dari proses bisnis telah dikembangkan. Paraakuntan memanfaatkan proses bisnis perusahaan dalam bentuk siklust ransaksi. Siklus transaksi (transaction cycles) mengelompokkan kejadian-kejadian terkaityang pada umumnya terjadi dalam suatu urutan tertentu. Kejadian (event) adalah aktivitas yang terjadi pada suatu waktu tertentu. Sebagai contoh, seorang pelanggan melakukan pemesanan, barang dikirimkan, dan laporan penjualan dicetak. Setiap siklus transaksi melibatkan beberapa kejadian. Terdapat tiga siklus transaksi utama:

1. Siklus pemerolehan / pembelian (acquisition / purchasingcycle) adalah proses pembelian dan pembayaran untuk barang-barang ataujasa.

2. Siklus konversi (convertion cycle) adalah proses mengubah sumber daya yang diperoleh menjadi barang-barang dan jasa.

3. Siklus pendapatan (revenue cycle) adalah proses menyediakan barang atau jasa untuk para pelanggan dan menagih uangnya. ${ }^{10}$

Menurut Romney dan Steinhart (2006) sistem

${ }^{9}$ SamiajiSarosa,SistemInformasiAkuntansi,(Jakarta:G rasindo, 2009),13

${ }^{10} \mathrm{D}$ asarathaV. Ramadan FrederickL. Jones,SistemInformasi.....,3-4

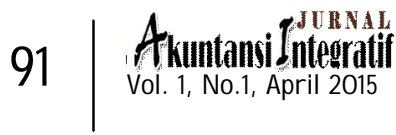


informasi akuntansi terdiri empat komponen:

1. Orang-orang yang mengoperasikan sistem tersebut dan melaksanakan berbagai fungsi.

2. Prosedur-prosedur, baik manual maupun yang terotomatisasi, yang dilibatkan dalam mengumpulkan, memproses, dan menyimpan data tentanga ktivitas-aktivitas organisasi.

3. Data tentang proses-proses bisnis organisasi.

4. Infrastuktur teknologi informasi, termasuk komputer, peralatan pendukung, dan peralatan untuk komunikasi jaringan.

Keempat komponen ini secara bersama-sama memungkinkan suatu sistem informasi akuntansi memenuhi tiga fungsi penting dalam organisasi, yaitu:

1. Mengumpulkan dan menyimpan data tentang aktivitas-aktivitas yang dilaksanakan oleh organisasi, sumber daya yang dipengaruhi oleh aktivitas-aktivitas tersebut, dan para pelaku yang terlibat dalam berbagai aktivitas tersebut, agar pihak manajemen, parapegawai, dan pihak-pihak luar yang berkepentingan dapat meninjau ulang hal-hal yang telah terjadi.

2. Mengubah data menjadi informasi yang berguna bagi pihak manajemen untuk membuat keputusan dalam aktivitas perencanaan, pelaksanaan, dan pengawasan.

3. Menyediakan pengendalian yang memadai untuk menjaga aset-aset organisasi, untuk memastikan bahwa data tersebut tersedia saat dibutuhkan, akurat, dan andal. 


\section{B. Pengendalian Internal}

1. Pengendalian Internaldan Peran Akuntan ${ }^{11}$

Pengendalianinternal (internalcontrol) adalah suatu proses, yang dipengaruhi oleh dewan direksi entitas, manajemen, dan personel lainnya, yang dirancang untuk memberikan kepastian yang beralasan terkait dengan pencapaian sasaran kategori sebagai berikut: efektivitas dan efisiensi operasi; keandalan pelaporan keuangan; dan ketaatan terhadap hukum dan peraturan yang berlaku.

Pemahaman yang baik mengenai pengendalian internal penting bagi akuntan yang berperan sebagai manajer, pengguna, perancang, dan evaluator sistem akuntansi.

a. Tanggung jawab manajer atas pengendalian internal telah dibuat secara eksplisit di Undang-Undang Sarbanes-Oxley Tahun 2002 dan Standar No. 2 Public Company Accounting Oversight Board (PCAOB). ${ }^{12}$ Standar No. 2 mengharuskan manajemen untuk membuat sebuah pertanyaan yang menjelaskan dan menilai system pengendalian internal perusahaan. Laporan tahunan perusahaan public saat ini harus mencakup (1) pernyataan bahwa manajemen

\footnotetext{
${ }^{11}$ D asarathaV. Ramadan FrederickL. Jones,Sistem Informasi....,132-133

${ }^{12}$ U ndang-U ndang Sarbanes-0 xleydihasilkandalampembentukanPublic $\mathrm{Company}$ Accounting $O$ versightBoard(PCAO B),yang diberdayakan untuk mengajukanstandar audit perusahaanpublik.SecurityandExchangeC ommission(SEC) harusmenyetujuisetiap standaragardapatdilaksanakan.PCAO Bmenyusun StandarAuditN 0.2,"AuditatasPengendalianInternal terhadapPelaporanKeuanganyangD ilakukandalam H ubungannya Keuangan. "StandarinidisetujuiolehSEC dalam RilisN 0.34-49884,17 Juni2004 
bertanggungjawab terhadap pengendalian internal atas pelaporan keuangan, pernyataan yang mengidentifikasi kerangka kerja yang digunakan oleh manajemen untuk mengevaluasi pengendalian internal, penilaian atas pengendalian internal dan pengungkapan adanya kekurangan material, dan (4) pernyataan bahwa kantor akuntan public telah menerbitkan laporan atestasi atas penilaian manajemen terhadap pengendalian internal.

b. Pengguna juga harus memahami pengendalian internal perusahaan sehingga dapat ditetapkan dengan tepat. Sebagai contoh, kebijakan manajemen mungkin mengharuskan bahwa detail faktur harus diverifikasi terhadap slip pengepakan dan pesanan pembelian (PO). Pengendalian seperti itu dikatakan efektif hanya jika orang yang bertanggungjawab atas pencatatan faktur memahami dan melakukan verifikasi ini.

c. Akuntan juga memiliki peran penting sebagai perancang prosedur pengendalian internal yang mendorong ketaatan terhadap peraturan dan sasaran perusahaan. Akuntan harus menilai risiko atas tidak tercapainya sasaran perusahaan dan sasaran pengendalian internal serta memilih atau merencanakan pengendalian internal yang dapat mengurangi risiko.

d. Dalam perannya sebagai evaluator, auditor internal dana uditor eksternal harus 
memahami system pengendalian internal. Auditor internal memainkan peran penting dalam mengembangkanl aporan manajemen yang menilai pengendalian internal, saat ini diharuskan oleh Standar PCAOB No. 2. Auditor eksternal perlu memahami pengendalian internal sehingga dapat menyusun atestasi atas pernyataan manajemen mengenai pengendalian internals ebagaimana diharuskan oleh standar tersebut. Tentu saja, auditor eksternal perlu memahami pengendalian internal sehingga mereka dapat melakukan audit atas laporan keuangan perusahaan. Standar audit yang berlaku umum memiliki banyak ketentuan bahwa auditor harus memperoleh pemahaman memadai mengenai pengendalian internal untuk merencanakan audit.

2. Konsep, Tujuan dan Unsur Pengendalian Internal Sistem pengendalian internal (internal control system) terdiri atas berbagai kebijakan, praktik, dan prosedur yang diterapkan oleh perusahaan untuk mencapai tempat tujuan umumnya: ${ }^{13}$

a. Menjaga aktiva perusahaan

b. Memastikan akurasi dan keandalan catatan serta informasi akuntansi.

c. Mendorong efisiensi dalam operasional perusahaan.

d. Mengukur kesesuaian dengan kebijakan serta prosedur yang ditetapkan oleh pihak manajemen.

${ }^{13}$ JamesA.H all, SistemInfo rmasiAkuntansi,(Jakarta:SalembaEm pat,2007),181

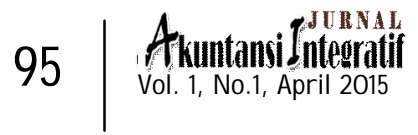


Tujuanutamapengendalianinternaladalah meyakinkan: ${ }^{14}$

a. Keandalan (reliabilitas dan integritas) informasi.

b. Kesesuaian dengan berbagai kebijaksanaan, rencana, prosedur, dan ketentuan perundangundangan;

c. Perlindungan terhadap harta organisasi;

d. Penggunaan sumber daya yang ekonomis dan efisien;

e. Tercapainya berbagaitujuandan sasaran yang telah ditetapkan.

Manajemen bertanggung jawab untuk merancang dan menerapkan lima unsur pengendalian internal (element sof internal control) untuk mencapai tujuan pengendalian internal. Unsur-unsur tersebut adalah sebagai berikut: ${ }^{15}$

a. Lingkungan pengendalian

b. Penilaian atau penetapan risiko

c. Prosedur pengendalian

d. Pemantauan (monitoring)

e. Informasidan komunikasi

\section{Zakat, Infak, dan Sedekah (ZIS)}

\section{Pengertian}

Ditinjau dari segi bahasa, kata zakat mempunyai beberapa arti, yaitu al-barakah' keberkahan', al-nama' 'pertumbuhan dan perkembangan', att-tlaha>ratu' kesucian' danas--

${ }^{14} \mathrm{H}$ iroT ugiman,StandarProfesionalAuditInternal,(Yogyakarta:Kanisius, 1997),44

${ }^{15} \mathrm{~W}$ arrenReeveFess,PengantarAkuntansi,(Jakarta:SalembaEmpat,2006),209 
słalah/u'keberesan'. Sedangkan secara istilah zakat ialah nama pengambilan tertentu dari harta tertentu, menurut sifat-sifat yang tertentu, dan untuk diberikan kepada golongant ertentu. ${ }^{16}$ Golongan tertentu itu sudah dijelaskan dalam AlQur'an surat At-Taubah ayat60 berikutini:

Artinya: Sesungguhnya zakat-zakat itu, hanyalah untuk orang-orang fakir, orang-orang miskin, pengurus-pengurus zakat, para mu'allaf yang dibujuk hatinya, untuk (memerdekakan) budak, orang-orang yang berhutang, untuk jalan Allah dan untuk mereka yang sedang dalam perjalanan, sebagai suatu ketetapan yang diwajibkan Allah, dan Allah Maha Mengetahui lagi Maha Bijaksana. ${ }^{17}$

Zakat merupakan salah satu rukun Islam, dan menjadi salah satu unsur pokok tegaknya syariat Islam. Oleh sebab itu hokum zakat adalah wajib (fardu) atas setiap muslim yang telah memenuhi syarat-syarat tertentu. Zakat termasuk dalam kategori ibadah (sepertisalat, haji, dan puasa) yang telah diatur secara rinci dan paten berdasarkan Al-Qur'an dan As-Sunnah, sekaligus merupakan amal sosial kemasyarakatan dan

Kemanusiaan yang dapat berkembang sesuai dengan perkembangan umat manusia. ${ }^{18}$ Sebagaimana firman Allah SWT dalam Al-Qur'an surat $\mathrm{An}-\mathrm{Nu}>\mathrm{r}$ ayat 56 berikut ini:

\footnotetext{
${ }^{16}$ M ujahidin Ahmad, Ekonomi Islam, (Jakarta: G rafindo Persada, 2007), 7

${ }^{17}$ Kementerian U rusan Agama Islam, W akaf, D akwah, dan Bimbingan Islam Kerajaan

Arab Saudi, Al-Q ur'an dan Terjemahnya, (Madinah: Mujamma' Al-Malik FahdLiAt\}-T\{ibar'at AlMushthffAl-Syarì,1418H),288

${ }^{18}$ Rifqi Muhammad ,Akuntansi Keuangan Syariah (Konsep dan Implementasi PSAK Syariah), (Yogyakarta: P3El Press, 2008), 390
} 
Artinya: Dan dirikanlah sembah yang, tunaikanlah zakat, dan taatlah kepada rasul, supaya kamu diberi rahmat. ${ }^{19}$

Infak merupakan harta (materiil) yang disunahkan untuk dikeluarkan dengan jumlah dan waktu yang tidak ditentukan. Penyalurannya tidak ditentukan penerimanya. Sedangkan sedekah adalah harta non materiil yang disunahkan untuk dikerjakan, contoh: senyum, menyingkirkan batu/paku ditengah jalan, dan lain sebagainya.Pengertian infak sebenarnya sama dengan pengertians edekah, termasuk juga hukum dan ketentuan-ketentuannya. Hanya saja, jika infak berkaitan dengan materi, sedekah memiliki arti lebih luas, menyangkut hal yang bersifat non materi. Secara akuntansi, infak masih mungkin untuk dihitung sedangkan sedekah tidak mudah melakukan kalkulasi secara tepat karena merupakan pemberian harta non materiil. ${ }^{20}$

Infak merupakan anjuran Allah untuk dikeluarkan kepada orang- orang fakir, seperti dalil Al-Qur'an surat Al-Baqarah ayat 273 dibawah ini:

Artinya: (Berinfaklah) kepada orang-orang fakir yang terikat (oleh jihad) dijalan Allah; mereka tidak dapat (berusaha) dimuka bumi; orang yang tidak tahu menyangka mereka orang kaya karena memelihara diri dari minta-minta.

${ }^{19}$ KementerianU rusanA gamalslam,W akaf,D akwah,dan 
Kamu kenal mereka dengan melihat sifatsifatnya, mereka tidak meminta kepada orang secara mendesak. Dana pasaja harta yang baik yang kamu nafkahkan (dijalan Allah), maka sesungguhnya Allah Maha Mengatahui. ${ }^{21}$

2. Lembaga PengelolaZIS

DiIndonesia, pengelolaan dana ZIS telah diatur dengan Undang-Undang No. 38 Tahun 1999 tentang pengelolaan zakat. Undang-undang ini mengatur tentang Organisasi Pengelola Zakat (OPZ) yang boleh beroperasi di Indonesia. OPZ yang disebutkan dalam undang-undang tersebut adalah Badan Amil Zakat (BAZ) dan Lembaga Amil Zakat (LAZ). BAZ merupakan lembaga pengumpul dan pendayagunaan dana zakat yang dibentuk oleh pemerintah dari tingkat pusat sampai dengan tingkat daerah, sedangkan LAZ merupakan OPZ yang dibentuk atas swadaya masyarakat.

Dalam perkembangannya LAZ lebih maju dan dinamis dibandingkan BAZ bahkan bentuk LAZ bias dikembangkan dalam berbagai kelompok masyarakat seperti takmir masjid, yayasan pengelola dana ZIS, maupun Unit Pengumpulan Zakat (UPZ) yang ada disetiap perusahaan yang berusaha mengorganisir pengumpulan dana ZIS dari direksi maupun karyawan.

Perkembangan BAZ dan LAZ di Indonesia perlu diikuti dengan proses akuntabilitas publik 
yang baik dan transparan dengan mengedepankan motivasi melaksanakan amanah umat. Pemerintaht elah mengatur tentang proses pelaporan bagi BAZ dan LAZ dengan Keputusan MenteriAgama RI Nomor 373 Tahun 2002 tentang pelaksanaan UU Nomor 38 Tahun 1999 tentang Pengelolaan Zakat Pasa 131 yang isinya: Badan Amil Zakat (BAZ) dan Lembaga Amil Zakat (LAZ) memberikan laporan tahunan pelaksanaan tugasnya kepada pemerintah sesuai dengan tingkatannya selambat-lambatnya 3 (tiga) bulan setelah akhir tahun.

Bahkan dalam alah satu syarat pendirian LAZ yang tertuang pada Pasal 22 SK Menteri Agama RI tersebut disebutkan bahwa untuk mendapatkan ijin dari pemerintah maka laporan keuangan LAZ untuk dua tahun terakhir harus sudah diaudit oleh Akuntan Publik. Selanjutnya, laporan keuangan LAZ tingkat pusat maupun provinsi harus bersedia diaudit oleh Akuntan Publikdan disurvey sewaktu-waktu oleh Tim dari Departemen Agama.

Dalam proses pelaporan keuangan BAZ dan LAZ selama ini sampai dengan SK Menteri Agama RI tersebut dikeluarkan, OPZ belum memiliki standar akuntansi keuangan sehingga terjadi perbedaan penyusunan laporan keuangan antara satu lembaga dengan lembaga lainnya. OPZ yang cukup inovatif kemudian menggunakan PSAK Nomor 45 tentang Pelaporan Keuangan Organisasi Nirlaba. Namun demikian, penggunaan PSAK tersebu ttidaklah mampu 
sepenuhnya mengatasi permasalahan standar akuntansi keuangan untuk OPZ. Sampai akhirnya pada tahun 2005, Forum Zakat berupaya untuk menyusun Pedoman Akuntansi bagi Organisasi Pegelola Zakat (PA-OPZ). ${ }^{22}$

3. Akuntansi ZIS

Akuntansi dapat didefinisikans ebagai proses pencatatan, penggolongan, peringkasan, pelaporan dan penganalisaan data keuangan suatu organisasi. ${ }^{23}$ Allah telah menjelaskan pentingnya menulis dalam hal Allah telah menjelaskan pentingnya menulis dalam hal muamalah sebagaimana firman Allah dalam AlQur'an surat Al-Baqarah ayat 282 berikut:

Artinya:.......hendaklah kamu menuliskannya.

Dan hendaklah seorang penulis diantara kamu menuliskannya dengan benar. Dan janganlah penulis enggan menuliskannya sebagaimana Allah mengajarkannya,....... ${ }^{24}$

Akuntansi juga diartikan, sebagai bahasa bisnis yang memberikan informasi tentang kondisi ekonomi suatu perusahaan atau organisas dan hasil usaha pada waktu atau periode tertentu, sebagai pertanggungjawaban manajemen serta untuk pengambilan keputusan. Dari pengertian definisi akuntansi di atas, menurut Husein Sahatah(1997) akuntansi zakatma>l dianggap sebagais alah satu cabang ilmu akuntansi yang dikhususkan untuk menentukan

${ }^{22}$ Rifqi M uhammad,AkuntansiKeuanganSyariah.....,389

${ }^{23}$ JusufAlharyono,D asar-D asarAkuntansi,jilidl, (Yogyakarta:YKPN ,2001),5

${ }^{24}$ KementerianU rusanAgamalslam,W akaf,D akwah, dan BimbinganlslamKerajaan Arab Saudi,Al-Q ur'andan......,70

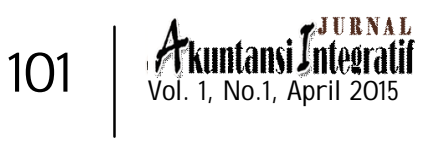


dan menilai asset wajib zakat, menimbang kadarnya (volume), dan mendistribusikan hasilnya kepada para mustah\}iq dengan berdasarkan kepada kaidah-kaidah syariat Islam. ${ }^{25}$ Berdasarkan pengertian tersebut maka yang menjadi tujuan dari akuntansi adalah pertangungjawaban, menjalankan fungsi manajemen (planning, organizing, actuating, controlling), pengawasan, sarana untuk pengambilan keputusan. Tujuan lainnya dari akuntansi zakat Menurut AAS-IFI Accounting \& Auditing Standard for Islamic Financial Institution) adalah menyajikan informasi mengenai ketaatan organisasi terhadap ketentuan syariah Islam, termasuk informasi mengenai penerimaan dan pengeluaran yang tidak diperbolehkan oleh syariah bila terjadi, serta bagaimana penyalurannya.

Berdasarkan tujuan tersebut maka memperlihatkan betapa pentingnya peran Dewan Syariah (mengeluarkan opini syariah). Akuntansi sebenarnya merupakan salah satu dalam kajian Islam. Artinya diserahkan kepada kemampuan akal pikiran manusia untuk mengembangkannya, karena akuntansi ini sifatnya urusan muamalah. Sehingga dapat disimpulkan bahwa nilai-nilai Islam ada dalam akuntansi dan akuntansi ada dalam struktur hukum dan muamalat Islam. ${ }^{26}$

Banyak orang menganggap bahwa salah satu

${ }^{25}$ M .ArifM ufraini, AkuntansidanM anajemenZ akat,(Jakarta:Kencana,2006),28.

${ }^{26}$ Sofyan SyafriH arahap, Akuntansilslam,(Jakarta:BumiAksara,2004),143.

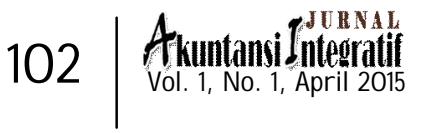


fungsi akuntansi Islam yang paling penting adalah Akuntansi Zakat, bahkan ada yang menganggap Akuntansi Islam itua dalah untuk menghitung zakat. Akuntansi Islam tidak hanya terbatas pada menghitungdan melaporkan zakat ini tetapi jauh lebih luas dari itu, karena akuntansi Islamj uga merupakan bagian dari system social umat sehingga akuntansi Islam juga harus dapat menciptakan kehidupan yang Islami sesuai syariat dan norma-norma Islam. ${ }^{27}$ Oleh karena itu para pakar Syariah Islam dan akuntansi harus mencari dasar untuk penerapan dan pengembangan standar akuntansi yang berbeda dengan standar akuntansi bank dan lembaga keuangan konvensional seperti telah dikenal selama ini, standar akuntansi tersebut menjadi kunci sukses badan pengelola zakat dalam melayani masyarakat disekitar. Sehingga seperti lazimnya, harus dapatmenyajikaninformasi yangcukup,dapatdipercayadanrelevan bagiparapenggunanya, namun tetapdalam kontekssyariah Islam.

Standar akuntansi zakat sesungguhnya mempunyai aturan tersendiri dengan melihat sifat zakat ini, standar akuntansi akan mengikuti bagaimana harta dinilai dan diukur. ${ }^{28}$ Secara umum standar akuntansi zakat akan dijelaskan sebagai berikut: penilaian dengan harga pasar sekarang, aturan satu tahun, kekayaan/aset, aktiva

\footnotetext{
${ }^{27}$ Sofyan SyafriH arahap, MenujuPerumusanTeoriAkuntansilslam,(Jakarta:Pustaka Q uantum,2001),297.

${ }^{28} \mathrm{Ibid}, 322$.
} 
tetap tidak kena zakat, nisłab (batas jumlah). Transaksi zakat adalah transaksiz akat, infak dan sedekah. Akuntabilitas organisasi pengelola zakat ditunjukkan dalam laporan keuangan tersebut, untuk bias disahkan sebagai organisasi resmi, lembaga zakat harus menggunakan system pembukuan yang benar dan siap diaudit akuntan publik. Ini artinya standar akuntansi zakat mutlak diperlukan. Karena dalam PSAK No.109, akuntansi zakat bertujuan untuk mengatur pengakuan, pengukuran, penyajian dan pengungkapan transaksiz akat,I nfak/shadaqah ${ }^{29}$

Sistem akuntansi dan pelaporan pada LAZ dapat dibagi menjadi dua bagian yaitu, untuk dana yangt erbatas (restricted funds) yaitu zakat dan infaq dan untuk dana yang tidak terbatas (unrestricted funds) yaitu dana shadaqah, meskipun demikian, sebagai satu kesatuan, organisasi ZIS harus menyiapkan satu laporan keuangan komprehensif (menyeluruh) yang menggabungkan aktivitas dan laporan keuangan kedua dana tersebut. ${ }^{30}$

Laporan keuangan Amil menurut PSAK No. 109 adalah neraca, (laporan posisi keuangan), laporan perubahan dana, laporan perubahan aset kelolaan, laporanaruskas, dan catatan atas laporan keuangan. ${ }^{31}$ Neracadan laporan penerimaan, pengeluaran dan perubahan dana untuk

\footnotetext{
${ }^{29}$ IkatanA kuntansilndonesia, "PSAKN 0.109",D ewanStandarAkuntansiKeuangan IkatanAkuntan Indonesia,2008

${ }^{30}$ D ahliaH eryani, "StudiPenerapanAkuntansiZakatStudiKasuspadaLAZPT.Semen Padangdan LAZISU II",U niversitasIslamIndonesia,Y ogyakarta:2005.

${ }^{31}$ IkatanA kuntansilndonesia,"PSAKN 0.109",D ewanStandarAkuntansiKeuangan IkatanAkuntanIndonesia,2008
} 
organisasi ZIS ini merupakan gabungan dari dua dana tersebut, yaitu dana zakat dan dana sedekah, sedangkan laporan perubahan posisi keuangan, dan catatan atas laporan keuangan perlu ditambahkan sehingga menjadi laporan keuangan yang menyeluruh yang menggambarkan kondisi keuangan organisasiZIS.

4. PSAKNo. $109^{32}$

Ikatan Akuntan Indonesia telah menyusun Exposure Draft (ED) PSAK No. 109 tentang Akuntansi Zakat dan Infak/Sedekah sebagai bagian dari penyempurnaan transaksi pengelolaan ZIS pada Lembaga Keuangan Syariah. Secara umum, semua LKS baik komersial maupun nirlaba memiliki transaksi pengelolaan dana ZIS baik dari individu di dalam entitas maupun dari luar entitas yang diamanahkan kepada LKS.

Secara khusus, LKS memiliki kompetensi untuk mengelola dana ZIS adala hOPZ yang berbentuk Badan Amil Zakat (BAZ), Lembaga Amil Zakat (LAZ), maupun Unit Pengumpul Zakat.

Pada Rancangan ED PSAK No. 109 yang pernah disusun oleh IAI sebagai satu tahap yang dilalui menuju penyusunan PSAK terdapat usulan bahwa ruang lingkup pemberlakuan PSAK tentang ZIS adalah entitas pembayar zakat, entitas pengelola (amil), dan entitas penerima zakat. Namun demikian, terdapat masalah manakala entitas pembayar zakat diusulkan

${ }^{32}$ Rifqi M uhammad,AkuntansiKeuanganSyariah.....,394-395

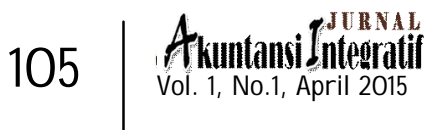


sebagai sala hsatu bagian yang mengikuti PSAK ini karena hakekatnya perusahaan (entitas) tidak wajib membayar zakat. Subyek yang memiliki kewajiban membayar zakat hanyalah individu saja sehingga Majelis Ulama Indonesia (MUI) menolak untuk mengeluarkan fatwa yang intinya perusahaan wajib mengeluarkan zakats eperti yang pernah diusulkan oleh IAI. Akhirnya ED PSAK No.109 tentang Akuntansi ZIS diusulkan hanya untuk Organisasi Pengelola Zakat saja sedangkan entitas pembayar dan entitas penerima diharapkan mengacu pada PSAK No.101 tentang Penyajiandan Pengungkapan Laporan Keuangan Syariah.

ED PSAK No. 109 dikeluarkan oleh IAI pada tanggal 26 Februari 2008 dan disosialisasikan ke public untuk mendapatkan tanggapan dan masukan demi perbaikan PSAK tersebut. Pada bagian ini akan diuraikan EDPSAK No.109 yang kemudian disimulasikan sehingga diharapkan akan diperoleh gambaran implementasi dan dampak pemberlakuan PSAK ini terhadap penyajian dan pengungkapannya. Menurut EDPSAK ini keempat jenis dana tersebut perlu dilakukan pencatatan secara spesifik dan tersendiri menurut sumber penghimpunan dan peruntukannya. Dalam website resmi Forum Zakat (FOZ) Ahmad Juwaini, Ketua Umum Forum Zakat Nasional menulis sebagai berikut: Penantian panjang itu akhirnya berakhir. Setelah hampir lima tahun pergumulan mengupayakan berlakunya Pernyataan StandarAkuntansi 
Keuangan (PSAK) untuk Organisasi Pengelola Zakat (OPZ), kini pemberlakuan itu telah menjadi nyata. Dimulai dengan pembahasan tentang pedoman akuntansi dan keuangan OPZ, yang kemudian berubah menjadi buku yang diterbitkan Forum Zakat (FOZ) pada tahun 2005.

Selanjutnya terjadi pembahasan tentang konsep PSAK Zakat yang dilakukan oleh Ikatan Akuntan Indonesia (IAI). Hasil pembahasan IAI ini kemudian diterbitkan menjadi Exposure Draft PSAK No.109 pada tahun 2008. Exposure Draft PSAK No. 109 ini kemudian terkendala oleh karena masih adanya beberapa permasalahan yang harus mendapatkan opini syariah (baca; fatwa) dari Dewan Syariah Nasional Majelis Ulama Indonesia (DSN MUI). Beberapa permasalahan dalam PSAK No.109 yang masih harus mendapatkan opini syariah dari DSN MUI tersebut adalah: 1) Biayaiklan/promosi yang dilakukan oleh OPZ; 2) Penyaluran zakat yang tidak langsung diterima mustahik; 3) Penyaluran dalam bentuk asset kelolaan oleh amil; 4) Penyaluran zakat kepada yayasan social; 5) Penyaluran zakat dalam bentuk pinjaman atau dana bergulir; 6) Investasi danazakat; 7) penyajian laporan dan anon halal dan; 8) Pengaturan zakat perusahaan. Akhirnya pada tahun 2011 ini opini syariah itu telah dikeluarkan. Bulan Ramadhan lalu telah menjadi angin segar, karena PSAK No.109 telah diselesaikan. Dalam bulan September atau Oktober 2011 ini, buku PSAK No.109 akan terbit dan dinikmati oleh kita semua. Ini artinya

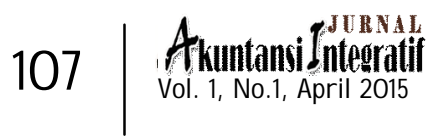


bahwa PSAK No.109 telah resmi berlaku. ${ }^{33}$

\section{Hasil Penelitian}

A. Proses Bisnis

Proses bisnis (business procces) yang ada pada BAZ di Jawa Timur secara umum mempunyai kesamaaan dan dapat disusun menjadi dua siklus utama, yakni siklus penerimaan/pendapatan dan siklus penyaluran/distribusi.

1. Siklus penerimaan/pendapatan mengacu pada proses penerimaan dana ZIS melalui para muzakki yang dibayarkan kepada BAZ baik secara langsung atau melalui transfer. Berikuta dalah proses bisnis mengenai penerimaan dana ZIS: Berikut ini adalah uraian dari setiap layanan pada sistem penerimaan ZIS yang terdapat pada BAZ di JawaTimur:

a. Muzakki, membayar ZIS kepada bagian Administrasi BAZ di Jawa Timur. Jika muzakki membayar melalui via transfer maka muzakki mengkonfirmasi kantor BAZ setempat dengan mengirimkan bukti transfer melalui facsimile dan media lainnya.

b. Bagian Administrasi, memberikan bukti pembayaran ZIS kepada muzakki. Jika muzakki membayar melalui via transfer maka langsung dicatat dalam rekapitulasi.

c. Bagian Keuangan, menerima dana ZIS yang sudah disetorkan oleh bagian Administrasi.

d. Bagian Administrasi, mencatat dalam 
rekapitulasi harian hingga bulanan.

e. Bagian Administrasi dan bagian Keuangan, bersama-sama memverifikasi penerimaan dana ZIS yang ada dalam data rekapitulasi.

f. Bagian Administrasi, membuat arsip jika sudah terkumpul data rekapitulasi dan buktit ransaksi dalam kurun waktu bulanan dan tahunan.

g. Bagian Keuangan, mendapatkan data tentang penerimaan dana ZIS baik rekapitulasi maupun setia pbukti transaksi dari bagian Administrasi untuk dijadikan bahan menyusun laporan keuangan.

2. Siklus penyaluran/distribusi mengacu pada proses penyaluran dana ZIS kepada mustahiq dengan program-progam yang sudah dibuat oleh BAZ dengan tujuan untuk mendayagunakan dana ZIS yang sudah diterima.

Berikut ini adalah uraian dari setiap layanan padasistem penerimaan ZISyang terdapatpada BAZ diJawaTimur:

a. Calon mustah\}iq, mengajukan permohonan kepada bagian Administrasi BAZ di Jawa Timur. Dengan membawa persyaratan yang sudah ditentukan.

b. Bagian Administrasi, mencatat pengajuan yang sudah masuk dan menyimpan persyaratan yang dibawa oleh calon mustah|iq.

c. Bagian Administrasi, menyortir semua data pengajuan dengan mendahulukan calon mustah\}iq yang paling membutuhkan.

d. Bagian Administrasi dengan jajaran pegawai BAZ, melaporkan data pengajuan yang sudah masuk kepada pengurus BAZ di Jawa Timur. 
e. Bagian Survei/Distribusi, melalui rekomendasi dari keputusan pengurus mensurvei para calon mustah\}iq yang sudah lolos penyaringan.

f. Bagian Survei/Distribusi, melaporkan hasil survei kepada bagian Administrasi untuk mempersiapkan dokumen-dukumen seperti bukti penerimaan dan dokumen lainnya jika hasil survei layak dan disetujui.

g. Bagian Keuangan, mencairkan sejumlah dana yang dibutuhkan sesuai dengan laporan dari bagian Administrasi.

h. Bagian Distribusi, mengirimkan dana atau bantuanl angsung kepada mustah/iq dengan membawa dokumen yang sudah disiapkan untuk ditandatangani oleh mustah\}iq.

i. Bagian Administrasi, mencatat rekapitulasi realisasi melalui dokumen yang dikembalikan oleh bagian Distribusi.

j. Bagian Keuangan, mendapatkan data tentang pendistribusian dana ZIS baik rekapitulasi maupun setiap bukti transaksi dari bagian Administrasi untuk dijadikan bahan menyusun laporan keuangan.

B. Komponen SistemlnformasiAkuntansi

MengenaikomponenSIAyangadapadaBAZdiJawa Timurada empatkomponen yang digunakanyakni sebagaiberikut:

a. Pegawai yang mencatat proses transaksi yang berlangsung pada BAZ.

b. Prosedur yang tidak tertulis( tidak ada prosedur khusus)

c. Data yang akan diolah seperti formulir, kwitansi 
dan lain-lain

d. Infrasutruktur pendukung seperti komputer, printer, scanner, dan peralatan lainnya.

C. PenggunaanSistemInformasiAkuntansi

1. Membuat laporan eksternal

BAZ menggunakan sistem informasi akuntansi untuk menghasilkan laporan-laporan khusus untuk memenuhi kebutuhan informasi dari para muzakki, pengurus BAZ, badan-badan pemerintah, dan yang lain. Laporan-laporan ini mencakup laporan keuangan, laporan pembayar ZIS, dan laporan yang diperlukan lainnya.

2. Mendukung aktivitas rutin

BAZ menggunakan sistem informasi akuntansi juga untuk mendukung aktivitas rutin contohnya antara lain pencatatan pemasukan dana ZIS, membuat kwitansi pembayaran dana ZIS, penyaluran dana ZIS, dan lain sebagainya.

3. Mendukung pengambilan keputusan Informasi juga diperlukan untuk mendukung pengambilan keputusan yang tidak rutin pada semua tingkat dari suatu organisasi. Contohnya antara lain mengetahui sektor mana yang mempunyai sumbangsih pembayar ZIS terbanyak dan sector mana yang harus diberikan dana ZIS. Informasi ini sangat penting untuk merencanakan target perolehan dana ZIS kedepan, memutuskan siapa dan daerah mana yang berhak memperoleh dana ZIS, dan menjaga para pembayar ZIS agar tetap percaya kepada BAZ.

4. Perencanaandan pengendalian

Perencanaan yang ada pada BAZ di Jawa Timur

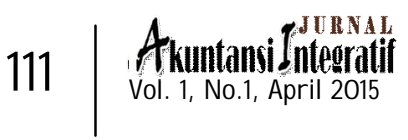


mayoritas adalah melalui program kerja yang sudah disusun oleh pengurus. Penulis belum menemukan proses perencanaan yang berasal dari penggunaan sistem informasi akuntansi.

5. Menerapkan pengendalian internal Pengendalian internal (internal control) yang ada pada BAZ di Jawa Timur masih mengacu pada pengendalian secara struktural bukan pada pengendalian secara sistematis. Dalam praktiknya pengendalian internal yang bertanggungjawab adalah komisi pengawas yang juga termasuk pengurus BAZ. Secara struktural jabatan masih berada di atas pegawai kantor atau pelaksana harian. Akan tetapi pengendalian yang dilakukan hanyalah secara berkala melalui rapat tahunan dan laporan pertanggungjawaban.

D. Akuntansi dan Teknologi Informasi

Modelakuntansi memungkinkan dua bentuk pemrosesan, yaitu pemrosesan transaksidan pemrosesan informasi.

1. Pemrosesan akuntansi

Pemrosesan akuntansi yang ada pada BAZ di Jawa Timur kebanyakan masih dilakukan menggunakan sistem yang sangat manual walaupun sebagian kecil ada yang masih menggunakan sistem komputerisasi. Dari semua tempat penelitian, sistemy ang sudah disediakan oleh BAZNAS yang berbentuk software pencatatan akuntansi tidak digunakan oleh BAZ di Jawa Timur.

2. Pemrosesan informasi

Pemrosesan informasi yang ada pada BAZ di 
Jawa Timur berawal dari siklus transaksi yang terjadi baik dari siklus penerimaan maupun penyaluran dana ZIS. Dari siklus tersebut tentunya didapati beberapa proses transaksi yang kemudaian diolah menjadi sebuah laporan keuangan. Dari laporan keuangan inilah BAZ di Jawa Timur melaporkan kepada pihak-pihak terkait baik melalui LPJ (Laporan Pertanggungjawaban) maupun laporan keuangan yang dimasukkan majalah sehingga nantinya akan bermanfaat.

\section{Kesimpulan}

Berdasarkan hasil analisis sistem informasi akuntansi pada BAZ di Jawa Timur, dapat ditari kesimpulan bahwa: 1. Penerapan sistem informasi akuntansi ZIS pada BAZ di Jawa Timur dapat disimpulkan tidak menggunakan SIA secara baik dan benar. Dengan alasan tidak digunakannya program pemrosesan transaksi yang dapat menciptakan sistem informasi akuntansi yang efektif dan efisisen, begitu juga dengan penomoran kwitansi bukti pembayaran ZIS peneliti menemukan bahwa BAZ di Jawa Timur tidak menggunakan kwitansi dengan penomoran permanen, sehingga dapa tterjadi potensi penyelewengan penerimaan dana ZIS, pengendalian internal yang ada di BAZ di Jawa Timur masih menggunakan pengendalian internaly ang dilaksanakan oleh pengurus dari masing-masing BAZ yang ada di Jawa Timur yang hanya mengacupada laporan pertanggungjawaban dari pelaksana harian/pegawai BAZ sehingga dapat berdampak 
pada kinerja organisasi.

2. Penerapan PSAK No.109 berdasarkan hasil analisis dapat disimpulkan bahwa BAZ diJawa Timur belum menggunakan PSAK No.109. Beberapa poin mengapa BAZ diJ awaTimur belum menggunakan PSAK No.109 adalah karena BAZ di Jawa Timur hanya menggunakan beberapa laporan arus kas saja. BAZ di Jawa Timur sebagian juga ada yang menggunakan Bank non Syariah maka semestinya ada akun' Dana Non Halal' akan tetapi pada laporan keuangannya tidak ada akun'Dana Non Halal'. Hal ini akan sangat berakibat fatal dalam pencatatan akuntansinya, karena tercampurnya dana yang didapat atau diperoleh. Sampai saat ini BAZ di Jawa Timur belum diaudit oleh akuntan publik, padahal menurut PSAK No. 109 adalah perlu adanya catatan atas laporan keuangan sehingga laporan keuangannya sesuai standar akuntansi.

\section{DaftarPustaka}

Andri Soemitra, Bank ,dan Lembaga Keuangan Syariah, Jakarta, Kencana, 2010.

Aprilia Ningsih, Penerapan Akuntansi Zakat pada Badan Amil Zakat (BAZ) Kabupaten Malang Malang, Universitas Muhammadiyah Malang, 2007.

Dahlia Heryani,S tudi Penerapan Akuntansi Zakat Studi Kasus pada LAZPT. Semen Padang dan LAZISUII, Yogyakarta, Universitas Islam Indonesia, 2005.

Dasaratha V. Rama, dan Frederick L. Jones, Sistem Informasi Akuntansi, Jakarta, Salemba Empat, 2008.

Didin Hafidhuddin, Zakat dalam Perekonomian Modern, Jakarta, Gema Insani Press, 2002. 
Hiro Tugiman, Standar Profesional Audit Internal, Yogyakarta, Kanisius, 1997.

James A. Hall, Sistem Informasi Akuntansi, Jakarta, Salemba Empat, 2007.

Jimmy L. Gaol, Sistem Informasi Manajemen, Jakarta, Grasindo, 2008.

Jusuf Al haryono, Dasar-Dasar Akuntansi, jilid I, Yogyakarta,YKPN, 2001.

Kementerian Urusan Agama Islam, Wakaf, Dakwah, dan Bimbingan Islam Kerajaan Arab Saudi, Al-Qur'an dan Terjemahnya, Madinah, Mujamma'

Al-Malik Fahd LiAt\}-T\{iba>'atAl-Mus\}h\}af Al-Syari $>$, $1418 \mathrm{H}$.

Marimin, et al., Sistem Informasi Manajemen Sumber Daya Manusia, Jakarta, Grasindo, 2006.

Marshall B. Romney dan Paul John Steinbart, Accounting Information System: Sistem Informasi Akuntansi, Jakarta, Salemba Empat, 2006.

Mujahidin Ahmad, Ekonomi Islam, Jakarta, Grafindo Persada, 2007.

M. Akhyar Adnan, Akuntansi Syariah Arah Prospek dan Tantangannya, Yogyakarta, UII Press, 2005.

M. Arif Mufraini, Akuntansi dan Manajemen Zakat, Jakarta, Kencana, 2006.

M.Faisal, Sistem Informasi Manajemen Jaringan, Yogyakarta, UIN Malang Press, 2008.

Rifqi Muhammad, Akuntansi Keuangan Syariah (Konsep, dan Implementasi PSAK Syariah), Yogyakarta ,P3EI Press, 2008.

Samiaji Sarosa, Sistem Informasi Akuntansi, Jakarta, Grasindo, 2009. 
Soeratnodan Lincolin Arsyad, Metodologi Penelitian Untuk Ekonomi, dan Bisnis, Yoyakarta, UPPSTIMYKPN, 2008.

Sofyan Syafri Harahap, Akuntansi Islam, Jakarta, Bumi Aksara, 2004.

Menuju Perumusan Teori Akuntansi Islam, Jakarta, Pustaka Quantum, 2001.

Suharsimi Arikunti, Prosedur Penelitian, Jakarta, Rineka Cipta, 2012

Tata Sutabri, Sistem Informasi Akuntansi, Yogyakarta, Andi Offset, 2004.

Warren Reeve Fess, Pengantar Akuntansi, Jakarta, Salemba Empat, 2006.

W. Gulo, Metodologi penelitian, Jakarta, Grasindo, 2002.

Badan Amil Zakat Pemerintahan Kabupaten Gresik, Laporan Keuangan Bulan November 2013.

BAZ Kota Mojokerto, Laporan Tahunan 2012.

Ikatan Akuntansi Indonesia, "PSAK No. 109", Dewan Standar Akuntansi Keuangan Ikatan Akuntan Indonesia, 2008.

Kementerian Agama, Undang-Undang No.38 Tahun 1999. Ahmad Juwaini, "Kini PSAK No. 109 Berlaku", dalam http://www.forumzakat.net/index.php?act=paparan\&i d=14(3Oktober2011)

Surabaya Post Online, "Potensi Zakat Rp 15 T, Hanya Tergali 1\%", dalam http://surabayapost.co.id/?mnu=berita\&act=view\&id=f57888add0 e4d4ba07f15fb95d3f7ad2\&jenis=d41d8cd98f00b204e980 0998ecf8427e(11Agustus2012)

Untung Dwiharjo, "Menguak Potensi Zakat di JawaTimur", dalam http://www.ydsf.org/blog/menguak-potensi-zakat-dijawa-timur(5Desember2011) 
Yusuf, "Mensejahterahkan Umat dengan Zakat", dalam http:/pirac.org/2012/05/25/mensejahterakan-umatdengan-zakat(25Mei2012) 